Portland State University

PDXScholar

Curriculum and Instruction Faculty Publications

and Presentations

Curriculum and Instruction

2003

Using Parent-Student Pairs for Internet Instruction

Micki M. Caskey

Portland State University, caskeym@pdx.edu

Follow this and additional works at: https://pdxscholar.library.pdx.edu/ci_fac

Part of the Curriculum and Instruction Commons

Let us know how access to this document benefits you.

Citation Details

Caskey, M. M. (2002). Using parent-student pairs for internet instruction. Journal of Research for Technology in Education, 34(3), 304-317.

This Article is brought to you for free and open access. It has been accepted for inclusion in Curriculum and Instruction Faculty Publications and Presentations by an authorized administrator of PDXScholar. Please contact us if we can make this document more accessible: pdxscholar@pdx.edu. 


\title{
Using Parent-Student Pairs for Internet Instruction
}

\author{
Micki M. Caskey \\ Portland State University
}

\begin{abstract}
Student and parent attitudes toward school-based Internet use were explored using parent-student pairs. An intergenerational approach positioned 54 pairs of young adolescents and their parents as co-learners for simultaneous Internet instruction, while another 51 parent-student pairs were given separate Internet instruction. This study examined the effect of instructional conditions using pre-and post-instruction attitude surveys and interviews. Survey analyses included descriptives, reliability measures, factor analysis, subscale formation, pre-and post-instruction comparisons, and analysis of variance of treatment and role variables. Interview analyses provided insights into student and parent attitudes. Positive effects of instruction were revealed for students and parents. (Keywords: attitudes, attitudes toward the Internet, diffusion of innovations, educational technology, intergenerational learning, parent involvement.)
\end{abstract}

School use of computers and the Internet is growing. For students to be able to meet the demands of higher education or future job markets, they must be proficient in communication and information technologies. Before teachers can effectively integrate communication and information technologies into instructional settings, they must understand how students become competent users of these technologies (Carmona, 1995; Collis, 1992). The increased school use of information and communication technology has the potential to strengthen learning and school-based instruction. To equip students with requisite skills and resources, a school-based Internet presence needs to be sustained. For educators and families of school-age children, the rapid emergence of the Internet creates both excitement and anxiety: though adolescents may be eager to explore the Internet, many parents are apprehensive about what the explorations might reveal. Clearly, much work needs to be done with regard to the delivery and use of the Internet in schools in ways that involve parents and garners their support.

Parental support is critical for the success of school use of the Internet. Many adolescents are more technologically literate and proficient users of technology than their parents. If parents are to be partners in their children's education, they must share a common base of knowledge and confidence about the ways the Internet will be used in schools.

Though parental involvement typically wanes around the time their child enters the middle grades, schools use a variety of strategies to increase parent involvement in school programs. These strategies include communicating with parents through newsletters, reports, and personal notes; family nights at school; parent handbooks; and providing a parent resource room in the school. Offering intergenerational Internet instruction adds to schools' repertoire of programs to engage parents. Coupled with many students' fascination with communication and information technologies, parents may engage in interesting and stimulating activities such as Internet instruction. 
Intergenerational instruction is an innovative approach to Internet instruction that enables parent-student pairs to sit shoulder-to-shoulder while exploring educational and ethical uses of Internet technologies. This opportunity allows students and their parents to become co-learners while strengthening their relationship and the home-school connection. Intergenerational instruction benefits the schools, parents, and adolescents as they pursue Internet literacy.

The purpose of this study was to evaluate the effects of intergenerational instruction on the attitudes of young adolescent students and their parents toward the school-based use of the Internet. In this study, students and parents were co-learners in a simultaneous learning experience.

\section{BACKGROUND}

Intergenerational programs in education bring adults and children together in learning. In this study, a parent-student pair approach was used with adolescent students and their parents for Internet instruction. A strong conceptual base for such an approach is found in the literature of several fields of study. However, previous reports of empirical evidence for the actual implementation of familyenhanced learning are limited.

\section{Educational Technology}

The effectiveness of educational technology has been widely researched. Studies on computer-based instruction aggregated in a meta-analysis by Kulik and Kulik (1991) indicated that computer-based instruction results in positive student outcomes. Specific research related to the effectiveness of Internet technologies is less available because of its recent emergence; however, initial data reveal positive effects on student and teacher attitudes and student achievement (Glennan \& Melmed, 1996). Educational technology is viewed as a natural and valuable tool in learner-centered, interactive environments where students are challenged with authentic and meaningful tasks (Dwyer, 1994; Means \& Olson, 1994). In summary, existing studies for computer-based instruction and Internet technologies report positive effects on student, parent, and teacher attitudes toward computers (Collis, 1992; Davidson \& Ritchie, 1994; Kulik \& Kulik).

The Internet, a powerful tool for learning, has recently become available in schools (Means \& Olson, 1995; National Center for Education Statistics [NCES], 2000a). As detailed by the NCES (2000b), school access to the Internet grew from $35 \%$ in 1994 to $50 \%$ in $1995,65 \%$ in 1996 , and $95 \%$ in 1999. Sixty-six percent of teachers reported using computers or the Internet for instruction during class time. This trend of growing Internet access appears to be continuing at present. Though Internet availability expands, many effects of school-based Internet access have yet to be reported.

\section{Diffusion of Innovations}

Reviews of diffusion efforts reveal that adoption and sustained use of innovations is dependent on a number of local factors, including locally situated expertise, organizational routines, and resources (Berman \& McLaughlin, 1978; 
Egermeier (1992) agree that local adaptation, support, and leadership must be present for dissemination of innovations and that individuals will use an innovation if it results in educational improvement (Sashkin \& Egermeier). An opti$\mathrm{mal}$ path for innovation diffusion is one that is mobilized with grassroots support and mutually adapted when integrated into educational practice (Berman \& McLaughlin; McLaughlin).

Adoption of innovations requires including relevant stakeholders (McLaughlin, 1989). Success depends on how the innovation is implemented by district, school, and community members (Berman \& McLaughlin, 1978). To this end, an innovation such as the Internet requires both training and support of the stakeholders.

Training that cognitively engages the participants with hands-on practice leads to increased knowledge and positive attitudes (Berman \& McLaughlin, 1978; Havelock, 1973; Rogers, 1983, 1995). Support for innovations increases when they are valued and meet the users' interests and needs. When parents, students, teachers, and other relevant stakeholders possess common knowledge and attitudes about an innovation, they encourage its use in both passive and active ways.

\section{Attitude Formation}

Kristiansen (1991) highlighted the crucial role of attitudes and expectations as important factors for the successful use of new information and communication technologies in education. Attitudes include cognitive, behavioral, affective, and social theoretical constructs (Bem, 1970; Olson \& Zanna, 1993; Zimbardo \& Leippe, 1991). Current studies suggest that teachers' attitudes toward technology are positive (Davidson \& Ritchie, 1994; Hadley \& Sheingold, 1993; Kristiansen; U.S. Congress, Office of Technology Assessment, 1995). Similarly, student and parent attitudes toward technology in general are very positive (Davidson \& Ritchie; Kristiansen). However, little research exists concerning student and parent attitudes toward information and communication technologies. Parents with limited Internet experience may doubt their own abilities while finding their children comfortable and ready to function in a technological world (Kristiansen). Parents' low levels of expertise coupled with high levels of apprehension may foster negative attitudes. These parental attitudes may, in turn, lessen the effectiveness of school-based Internet instruction.

\section{Intergenerational Learning}

Intergenerational learning is an emergent field of inquiry that had its early focus on literacy development (Askov, Maclay, \& Bixler, 1992; Auerbach, 1989; Nickse, 1990, 1992; Snow \& Tabors, 1996). One intergenerational learning study that used technology (Askov et al.) found positive effects on both parent and student attitudes. For parents, "the use of computers offers a 'face-saving' and modern way to learn to read and write" (Askov et al., p. 157). In addition, these researchers maintain that co-instruction sends a strong message about the importance of school and education. Similarly, positive changes in the attitudes of elementary and secondary school students occur when their parents attend the computer-based, intergenerational learning program. 


\section{Parent Involvement}

Research on parent involvement in schools has examined parent participation rates at both the middle and high school levels. It has also looked at the effects of parent involvement on student achievement and student and parent attitudes. Parent involvement is a significant predictor of academic success and has a positive effect on student achievement (Chavkin \& Williams, 1990; Cohen, 1994; Cotton \& Wikelund, 1989; Epstein, 1995; Foster-Harrison \& Peel, 1995). Chavkin and Williams stress, "the evidence that parent involvement improves student achievement is now incontrovertible" (p. 242). Furthermore, parent involvement has similar positive effects on student and parent attitudes toward school, learning, and specific subjects (Chavkin \& Williams; Cotton $\&$ Wikelund; Epstein). Students feel more secure, work harder, and stay in school longer when parents are involved (Epstein). Parents sense the importance of the contribution they make to their children's learning, which, in turn, improves parent self-concept (Cotton \& Wikelund). Parent involvement increases the interaction between schools and families, which leads to positive attitude change for both groups (Auerbach, 1989).

Parent involvement in school typically declines, however, as students move from the elementary grades to middle school and high school (Cohen, 1994; Epstein, 1995; Foster-Harrison \& Peel, 1995; Lewis, 1992). Organizational structures of middle and high schools tend to impede parent involvement (Cotton \& Wikelund, 1989), as do parents' schedules and time constraints (Foster-Harrison \& Peel). Adolescent development characteristics themselves influence parent involvement. Students assert their independence and need for autonomy, including direct requests that their parents not come to school (Cohen; Foster-Harrison \& Peel). Nevertheless, parents participate more often when they believe the school encourages their involvement (Dauber \& Epstein, 1989; Epstein \& Dauber, 1989). Intergenerational learning programs afford parents opportunities to become colearners with their adolescent children in authentic and meaningful ways.

\section{THE STUDY}

Adolescents' eagerness to use the Internet is often met with parental hesitation. Parental reluctance may be based on issues related to Internet content, their own Internet proficiency, and unfamiliarity with the Internet as an educational innovation. For example, parents are concerned about the Internet's inappropriate material of a sexual or violent nature as well as their children being harassed by unkind or harmful e-mail and bulletin board messages (National Center for Missing and Exploited Children, 1998). Some parents question the quantity and quality of information on the Internet. Parental attitudes are affected by their own use of Internet technology at work and home. Additionally, Internet use at school is a departure from the conventional instructional practices that parents understand. When unresolved, parental concerns foster negative attitudes toward the Internet. The problem addressed in this study involves understanding how to bridge the gap between parent and student attitudes; the task is to reduce parental misgivings and maintain student enthusiasm toward using the Internet. 


\section{Research Question}

The central question addressed in this study was: does the pairing of family members in Internet training make a significant difference in the outcomes of the training?

\section{Study Design}

This study was a true experiment in which 105 parent-child volunteer pairs were randomly assigned to two treatment groups. In one treatment group, Internet instruction was provided separately to parents and students. In the second treatment group, the same instruction was given to parents working in pairs with their own children.

\section{Data and Analysis}

Data for this study consisted of a demographic description of the sample and participant self-reports on 25-item surveys administered before and after the training program. The surveys for parent and students had similar items, but were worded differently to be appropriate for each family role. Both surveys are presented in Appendix A (online at www.iste.org/jrte).

Demographic data gathering and analysis included age, pupil grade, gender, ethnicity, and location of current Internet access. School and district characteristics, such as ethnicity and socioeconomic status, were also described.

Survey analysis included descriptives of item and total scale, reliabilities (alpha) of each survey, factor analysis, subscale formation, pre- and postinstruction comparisons of items and subscales, and analysis of variance of the treatment and role variables. The factor analysis served as a confirmatory analysis and provided information for construction of subscales to better understand how components of the attitudes and cognitive self-reports fared in training and grouping. Subscales were constructed from the factor analysis by summing the two of three items with the highest factor loadings.

\section{FINDINGS}

Data for this study consisted of participant responses on a survey of attitudes and interviews about Internet usage and instruction in school and family settings. This section first reports the findings from the attitude survey and then describes what was learned from the interviews.

\section{Survey Findings}

\section{Survey Scale Statistics: Internal Reliabilities and Factor Structures}

The internal reliability (Cronbach alpha) of the 25-item Internet Survey for Students was found to be 0.79; that of the Internet Survey for Parents was found to be 0.85 . These values are in the range of reliabilities generally considered acceptable for research instruments.

A factor analysis revealed that the two populations had different underlying factor structures in their responses to the survey items. As shown in Table 1, the parent survey was found to have five factors with a combination of eigenvalue more than 1.0 and explained variance greater than $5 \%$. As shown in Table 2 , 
the student survey was found to have six factors with a combination of eigenvalue more than 1.0 and explained variance greater than $5 \%$.

\section{Pairwise Contrast of Pre-instruction Scores between Parents and Students}

The surveys were administered to both the parents and students before instruction began to determine if the two groups differed significantly in their attitudes toward Internet use in schools. The parent and student pre-instruction surveys showed a statistically significant difference between the groups, $t=3.19$, $d f=208, p<.01$. The students began with a higher scale score (more positive attitudes) than did the parents.

\section{Pairwise Contrasts Because of the Instruction}

The surveys were again administered to participants after instruction to determine if the instruction caused a statistically significant change in attitudes. Both the student and parent populations showed statistically significant increases in scaled scores: parents, $t=6.42, d f=104, p<.01$; students, $t=9.74, d f=104$, $p<.01$. This means that the instruccion was effective for both groups.

Because of the multifactor complexity of both surveys, a subscale (factor) comparison was made by time (pre-instruction and post-instruction). Table 3 presents the mean differences between administration for both parent and student subscales. Parents showed a statistically significant increase on four of the five subscales; students showed a statistically significant increase on four of their six subscales. This means that the training enhanced most but not all attitude factors.

\section{Pairwise Contrast Because of Treatment Group}

The difference in parent post-instruction scores between trearment groups was found to be statistically significant, $t=2.74, d f=103, p<.01$, though the corresponding scores for students according to treatment were not found to be significantly different, $t=1.11, d f=103, p=.27$. This means that parents who received training with their children experienced more positive change in their attitudes toward Internet use than parents trained separately.

Because of the multifactor complexity of both surveys, a subscale (factor) comparison was made by treatment (separate or in pairs). Table 4 presents the mean difference between administrations for both parent and student subscales. Parents showed a statistically significant increase on two of the five subscales; students showed a statistically significant increase on none of their six subscales. This means that the paired instruction made a difference for parents on some attitude factors but made no difference for the students.

\section{Multiple Classification of Analysis}

The survey results were analyzed by subgroup means to determine if the role in the family (parent or child) and the effect of the treatment (separate or in pairs) made a difference in post-instruction attitudes about Internet use in school. Table 5 shows the mean total scale scores on the post-instruction use of the two attitude surveys. These scores were adjusted using pre-instruction scores as a covariate because of the statistically significant differences of student and 


\section{Table 1. Parent Survey Factor Structure}

Factor 1 (eigenvalue $=6.25$; explained variance $=25.0 \%$ )

The Internet should be provided at school as a valuable tool to use.

.83 Schools should provide students with Internet access. (1)

.79 The Internet is a valuable tool for use in schools. (2)

.73 All students need to know how to use the Internet. (3)

Factor 2 (eigenvalue $=2.70$; explained variance $=10.8 \%$ )

The Internet helps students feel confident and benefit from information.

.77 The Internet helps students to feel confident in research. (15)

.73 The Internet helps students to feel confident in communication. (16)

.72 Students benefit from the information on the Internet. (17)

Factor 3 (eigenvalue $=2.27$; explained variance $=9.1 \%$ )

I am a skilled, knowledgeable user and comfortable with my child.

.89 I am a skilled user. (10)

.88 I know enough to assist my child. (11)

.72 I am comfortable working with my child. (13)

Factor 4 (eigenvalue $=1.78$; explained variance $=7.1 \%$ )

I worry about hurtful, inappropriate material and the risks of Internet use.

.81 I am fearful of unkind or hurtful e-mail messages. (20)

.76 I worry that my child may be exposed to inappropriate material. (19)

.72 The Internet poses risks for members of my family. (21)

Factor 5 (eigenvalue $=1.52 ;$ explained variance $=6.1 \%$ )

In this school, teachers use the Internet well.

.85 In this school, teachers know how to use the Internet. (24)

.73 Teachers adequately supervise students. (22)

parent pre-instruction attitudes. Table 5 presents the group values by role and treatment, the analysis of variance, and beta (explained variance) of scores adjusted for independent variables and covariate. The combined variables explained $33.0 \%$ of the observed variance in post-instruction survey scores. This amount of explained variance is generally considered important information for an educational study.

\section{Summary of Findings Derived from Survey Analyses}

Survey findings were derived from several analyses. Reliability estimates for the parent and student survey results were sufficient, as evidenced by Cronbach alpha levels. Factor analyses identified a number of underlying factors, five for 


\section{Table 2. Student Survey Factor Structure}

Factor 1 (eigenvalue $=5.02$; explained variance $=20.1 \%)$

I may see unkind, hurtful, threatening, or risky material on the Internet.

.75 I am fearful of unkind or hurtful e-mail messages. (20)

.75 The Internet poses risks for my family. (21)

.64 I may be exposed to inappropriate material. (19)

Factor 2 (eigenvalue $=3.17$; explained variance $=12.7 \%$ )

The Internet has value, and I am comfortable using it with my parents.

.74 Students need to know how to use the Internet. (3)

.64 I am comfortable working with my parents. (13)

.56 I like using the Internet. (9)

Factor 3 (eigenvalue $=1.75$; explained variance $=7.0 \%$ )

Internet training is important for teachers, students, and parents.

.75 Teachers need training to guide student Internet use. (23)

.73 I am interested in learning more about the Internet. (8)

.56 Providing Internet training for parents is important. (25)

Factor 4 (eigenvalue $=1.48$; explained variance $=5.9 \%$ )

The Internet helps students feel confident doing research or communicating.

.83 The Internet helps students feel confident in doing research. (15)

.75 The Internet helps students feel confident communicating. (16)

Factor 5 (eigenvalue $=1.40$; explained variance $=5.6 \%)$

Internet use interferes with basic skill learning; it is not as good as books for information.

.75 When students use the Internet, they miss learning basic skills. (6)

.71 It is better to use books than the Internet to find information. (5)

Factor 6 (eigenvalue $=1.31 ;$ explained variance $=5.2 \%)$

I am a skilled user, and I know enough to belp my parent.

.78 I am a skilled user of the Internet. (10)

.75 I know enough about the Internet to help my parent. (11)

parents and six for students, which explained the variance observed in the 25item attitude surveys. These underlying factors were used for pairwise contrast and multiple classification analyses. Pre-instruction scores of the parents and students revealed that the initial attitudes of the participants were different. Consequently, scaled scores were used in the subsequent analyses. The scaled scores indicated that Internet instruction was effective for both parents and stu- 


\begin{tabular}{|c|c|c|c|c|c|}
\hline \multicolumn{6}{|l|}{ Parents } \\
\hline Factor & Time & $M$ & $t$ & $d f$ & $p$ \\
\hline \multirow[t]{2}{*}{1} & Before & 13.28 & & & \\
\hline & After & 13.77 & 2.84 & 104 & $<.01$ \\
\hline \multirow[t]{2}{*}{2} & Before & 12.46 & & & \\
\hline & After & 12.57 & 0.70 & 104 & .49 \\
\hline \multirow[t]{2}{*}{3} & Before & 8.69 & & & \\
\hline & After & 9.91 & 6.32 & 104 & $<.01$ \\
\hline \multirow[t]{2}{*}{4} & Before & 8.51 & & & \\
\hline & After & 9.71 & 4.65 & 104 & $<.01$ \\
\hline \multirow[t]{2}{*}{5} & Before & 7.65 & & & \\
\hline & After & 8.00 & 3.05 & 104 & $<.01$ \\
\hline \multicolumn{6}{|c|}{ Students } \\
\hline Factor & Time & $M$ & $t$ & $d f$ & $p$ \\
\hline \multirow[t]{2}{*}{1} & Before & 10.97 & & & \\
\hline & After & 11.97 & 4.49 & 104 & $<.01$ \\
\hline \multirow[t]{2}{*}{2} & Before & 12.47 & & & \\
\hline & After & 13.56 & 6.49 & 104 & $<.01$ \\
\hline \multirow[t]{2}{*}{3} & Before & 12.32 & & & \\
\hline & After & 12.67 & 1.55 & 104 & .12 \\
\hline \multirow[t]{2}{*}{4} & Before & 8.30 & & & \\
\hline & After & 8.51 & 1.75 & 104 & .08 \\
\hline \multirow[t]{2}{*}{5} & Before & 7.42 & & & \\
\hline & After & 8.21 & 4.58 & 104 & $<.01$ \\
\hline \multirow[t]{2}{*}{6} & Before & 6.10 & & & \\
\hline & After & 7.89 & 9.56 & 104 & $<.01$ \\
\hline
\end{tabular}

dents. Though scaled scores revealed that parents preferred family pairing, no preference in treatment was evidenced for students. Comparisons of group means showed a statistical difference in parent and student post instruction mean scores and significant two-way interaction between family role and treatment. A positive relationship between role and treatment variables was found, which accounted for $33 \%$ of the observed variance in the scaled scores on the attitude surveys.

\section{Interview Findings}

Interview data revealed that Internet instruction had a positive effect on student use of the Internet and the level of family involvement in the school.

The tangible outcome of Internet instruction for adolescents in both training conditions was the privilege of Internet access at school. All interviewed students reported Internet use during the instructional day, with 50\% reporting daily use. Importantly, $70 \%$ of the students indicated they were more comfortable using the Internet at school than at other locations, even though $50 \%$ of the students had access to the Internet outside school. As evidenced by the ma- 
Table 4. Attitudes Survey Subscale Differences by Treatments

\begin{tabular}{|c|c|c|c|c|c|}
\hline \multicolumn{6}{|l|}{ Parents } \\
\hline Factor & Condition & $M$ & $t$ & $d f$ & $p$ \\
\hline \multirow[t]{2}{*}{1} & Separate & 13.51 & & & \\
\hline & Paired & 14.02 & 1.75 & 103 & .08 \\
\hline \multirow[t]{2}{*}{2} & Separate & 12.37 & & & \\
\hline & Paired & 12.76 & 1.21 & 103 & .23 \\
\hline \multirow[t]{2}{*}{3} & Separate & 9.78 & & & \\
\hline & Paired & 10.04 & .48 & 103 & .63 \\
\hline \multirow[t]{2}{*}{4} & Separate & 8.92 & & & \\
\hline & Paired & 10.46 & 3.68 & 103 & $<.01$ \\
\hline \multirow[t]{2}{*}{5} & Separate & 7.76 & & & \\
\hline & Paired & 8.22 & 2.01 & 103 & $<.05$ \\
\hline \multicolumn{6}{|c|}{ Students } \\
\hline Factor & Condition & $M$ & $t$ & $d f$ & $p$ \\
\hline \multirow[t]{2}{*}{1} & Separate & 11.86 & & & \\
\hline & Paired & 12.07 & .48 & 103 & .63 \\
\hline \multirow[t]{2}{*}{2} & Separate & 13.67 & & & \\
\hline & Paired & 13.46 & .74 & 103 & .46 \\
\hline \multirow[t]{2}{*}{3} & Separate & 12.61 & & & \\
\hline & Paired & 12.72 & .30 & 103 & .77 \\
\hline \multirow[t]{2}{*}{4} & Separate & 8.67 & & & \\
\hline & Paired & 8.37 & 1.17 & 103 & .25 \\
\hline \multirow[t]{2}{*}{5} & Separate & 8.37 & & & \\
\hline & Paired & 8.06 & 1.28 & 103 & .20 \\
\hline \multirow[t]{2}{*}{6} & Separate & 8.14 & & & \\
\hline & Paired & 7.65 & 1.69 & 103 & .09 \\
\hline
\end{tabular}

jority of student responses, the Internet was used primarily for schoolwork. Specifically, students noted using the Internet to find information or pictures and to explore Web sites, and they were able to name specific search engines that assisted their research efforts. Students used the Internet less often for entertainment, with only $25 \%$ reporting recreational use more than once a week. Overall, adolescents reported their experiences with the Internet to be frequent, informative, and positive.

The Internet instruction program also positively affected family involvement. After instruction, 25\% of the parents interviewed reported being more involved with the school. Though family involvement increased for only $25 \%$, the majority of both parents and teachers stated that a high level of parent involvement already existed at the school. Notably, every parent arranged his or her schedule to participate in the Internet instruction program. In addition, $40 \%$ of the teachers and $25 \%$ of the parents reported using the Internet to communicate about student performance and school programs. Importantly, parents indicated their willingness to visit the school when invited. A major effect of Inter- 
Table 5. Multiple Classification Analysis of Post Instruction Survey Results (Scores Adjusted by Pre-instruction Survey Score)

Scale Score of Total Population $(N=210)$

102.45

Scale Score by Independent Variables

$\begin{array}{llr}\text { Role } & \text { Parent } & 99.54 \\ & \text { Student } & 105.36 \\ \text { Treatment } & \text { Separate } & 101.73 \\ & \text { Paired } & 103.14\end{array}$

Scale Score by Treatment Groups

$\begin{array}{llcl}\text { Treatment } & & \text { Separate } & \text { Paired } \\ \text { Role } & \text { Parent } & 97.20 & 101.76 \\ & \text { Student } & 106.25 & 104.52\end{array}$

\begin{tabular}{lcrc} 
Source of Variation & $d f$ & \multicolumn{1}{c}{$F$} & $p$ \\
Covariate & 1 & 87.20 & $<.01$ \\
Main Effects & 2 & 9.71 & $<.01$ \\
$\quad$ Role & 1 & 15.71 & $<.01$ \\
$\quad$ Treatment & 1 & 3.53 & .06 \\
2-Way Interaction & & & \\
$\quad$ Role X Treatment & 1 & 11.37 & $<.01$ \\
Explained & 4 & 29.50 & $<.01$
\end{tabular}

Variable $\quad \beta$ (adjusted for Independents \& Covariate)

Role $\quad .23$

Treatment $\quad .10$

Mult R $\quad .575$

Mult R ${ }^{2} \quad .330$

net instruction on family involvement was that parents declared they felt more comfortable at school.

\section{DISCUSSION}

The Internet instruction approach that was the focus of this study was effective in increasing positive attitudes of students and their parents toward the Internet in schools. This finding is important because it endorses the use and benefits of Internet-enhanced instruction in the schools. It also corroborates the findings of Collis (1992), who found strong support for the school-based use of telecommunications. Additionally, it confirms a Rand study (Glennan \& Melmed, 1996) that reported that the use of information technologies in schools improved student attitude and engagement.

A central finding of this study was that the paired instruction made a difference for the parents overall, in particular for confidence factors. Beforehand, one parent said, "I worry about hurtful, inappropriate, and risks of Internet use." It is important that parents experience firsthand the essential skills and attitudes of 
school-based Internet use. Parents benefit from the interaction with their children in developing confidence in both competence and responsibility. Secondhand or virtual reassurance is not as effective as immediate experience. This is critical, because parents are more likely to support innovative programs when their confidence is high. This is particularly true in the protection of minors.

The strong positive effect of training parents is key to subsequent student growth. As described by Cotton and Wikelund (1989), parent involvement, such as active support of subject matter and participation in school-based activities, results in greater student achievement. In this study, though the effect of pair instruction on students was not statistically significant, the indirect benefit of parent-student approach was realized.

One particular significant subscale increase was of special interest to educators. The subscale, "in this school, teachers use the Internet well," was not directly observed by parents; however, their attitudes increased in a positive direction. This is important for educators who are interested in fostering support of public schools and their programs.

In the subscale analysis for change in attitude by time, one parent subscale and two student subscales did not show statistically significant change. The parent ("the Internet helps students to feel confident and benefit from information") and student ("the Internet helps students to feel confident") subscales may not have increased because each referred to behaviors and results that would have been subsequent to this study. The other student subscale ("Internet training is important for teachers, students, and parents") includes a reference to teacher training that the students did not experience.

The surveys used in this study established their utility and defensibility for better understanding Internet instruction in middle schools. Nevertheless, the subsequent factor analysis suggests that two briefer, more focused sets of items and audience-specific forms would target pertinent issues more directly.

Importantly, this study revealed that using parent-student pairs for Internet instruction helped diminish the difference between parent and student attitudes toward Internet use in schools. As an emerging field of inquiry, further research is needed to explore and substantiate the use of this intergenerational approach for Internet instruction or other innovative programs in public schools.

\section{Contributor}

Micki M. Caskey is an assistant professor in curriculum and instruction in the Graduate School of Education at Portland State University. Dr. Caskey teaches and leads preservice cohorts in the Graduate Teacher Education Program. Her areas of specialization include middle-level education, field-based teacher education, and curriculum and technology integration. (Address: Micki M. Caskey, Graduate School of Education, Portland State University, PO Box 751, Portland, OR 97207-0751; caskeym@pdx.edu.)

\section{References}

Askov, E. N., Maclay, C. M., \& Bixler, B. (1992). An intergenerational study of the impact of computer-assisted instruction with low-literate parents. In 
T. G. Sticht, M. J. Beeler, \& B. A. McDonald (Eds.), The intergenerational transfer of cognitive skills, Volume I: Programs, policies, and research issues (pp. 149-158). Norwood, NJ: Ablex.

Auerbach, E. R. (1989). Toward a social-contextual approach to family literacy. The Harvard Education Review, 59(2), 165-181.

Bem, D. J. (1970). Beliefs, attitudes, and buman affairs. Monterey, CA: Brooks/Cole.

Berman, P., \& McLaughlin, M. W. (1978). Federal programs supporting educational change, Vol. VIII: Implementing and sustaining innovations. Santa Monica, CA: The Rand Corporation. (ERIC No. ED 159 289)

Carmona, J. (1995). The Internet: Opening doors for education. T.H.E. Journal, 23(1), 10.

Chavkin, N. F., \& Williams, D. L. (1990). Working parents and schools: Implications for practice. Education, 111(2), 242-248.

Cohen, D. (1994). Parent involvement drops off after early grades. Education Week, 14(1), 6-8.

Collis, B. (1992). Supporting educational uses of telecommunication in the secondary school: Part II. Strategies for improved implementation. International Journal of Instructional Media, 19(2), 97-109

Cotton, K., \& Wikelund, K. R. (1989). Parent involvement in education. School Improvement Research Series [Online document]. Portland, OR: Northwest Regional Educational Laboratory. Available: www.nwrel.org/scpd/sirs/3/ cu6.html.

Dalton, D. (1989). Computers in the schools: A diffusion/adoption perspective. Educational Technology, 29(11), 20-27.

Dauber, S. L., \& Epstein, J. L. (1989). Parent attitudes and practices of parent involvement in inner-city elementary and middle schools. Report No. 33. Baltimore: Center for Research on Elementary and Middle Schools. (ERIC No. ED 314 152)

Davidson, G., \& Ritchie S. (1994). Attitudes toward integrating computers into the classroom: What parents, teachers, and students report. Journal of Computing in Childhood Education, 5(1), 3-27.

Dwyer, D. C. (1994). Apple Classrooms of Tomorrow: What we've learned. Educational Leadership, 51(7), 4-10.

Epstein, J. (1995). School/family/community partnerships. Phi Delta Kappan, 76(9), 701-712.

Epstein, J. L., \& Dauber, S. L. (1989). Teacher attitudes and practices of parent involvement in inner-city elementary and middle schools. Report No. 32. Baltimore:

Center for Research on Elementary and Middle Schools. (ERIC No. ED 314 151)

Foster-Harrison, E. S., \& Peel, H. A. (1995). Parent in the middle: Initiatives for success. Schools in the Middle, 5(2), 45-47.

Glennan, T. K., \& Melmed, A. (1996). Fostering the use of educational technology: Elements of a national strategy. Washington, DC: The Rand Corporation.

Hadley, M., \& Sheingold, K. (1993). Commonalities and distinctive patterns in teachers' integration of computers. American Journal of Education, 10(3), $261-315$. 
Havelock, R. G. (1973). The change agent's guide to innovation in education. Englewood Cliffs, NJ: Educational Technology Publications.

Kristiansen, R. (1991). Consensus on computers in education: Do teachers, parents, and pupils share the same expectations and attitudes towards computers? Education and Computing, 7(3-4), 199-207.

Kulik, C. C., \& Kulik, J. A. (1991). Effectiveness of computer-based instruction: An updated analysis. Computers in Human Behavior, 7(1-2),75-94.

Lewis, A. (1992). Parents care, do schools? A look at the research. Schools in the Middle, 2(2), 10-11.

McLaughlin, M. W. (1989). The RAND change agent study ten years later: Macro perspectives and micro realities. (ERIC No. ED 342085 )

Means, B., \& Olson, K. (1994). The link between technology and authentic learning. Educational Leadership, 51(7), 15-18.

Means, B., \& Olson, K. (1995). Technology and education reform. Volume II: Case study reports. (ERIC No. ED 397 560)

National Center for Education Statistics. (2000a). Internet access in U.S. public schools and classrooms: $1994-99$ [Online document]. Washington, DC: Author. Available: http://nces.ed.gov/pubs2000/2000086.pdf.

National Center for Education Statistics. (2000b). Teacher use of computers and the Internet in public schools [Online document]. Washington, DC: Author. Available: http://nces.ed.gov/pubs2000/2000090.pdf.

National Center for Missing and Exploited Children. (1998). Child safety on the information highway. Arlington, VA: Author.

Nickse, R. S. (1990). Family and intergenerational literacy programs. An update of "the noises of literacy." (ERIC No. ED 327 736)

Nickse, R. S. (1992). Family and intergenerational literacy practices at the Family Learning Center: One voice of experience. In T. G. Sticht, M. J. Beeler, $\&$ B. A. McDonald (Eds.), The intergenerational transfer of cognitive skills, Volume I: Programs, policies, and research issues (pp. 122-135). Norwood, NJ: Ablex.

Olson, J. M., \& Zanna, M. P. (1993). Attitudes and attitude change. Annual Review of Psychology, 44, 117-154.

Rogers, E. (1983). Diffusion of innovation (3rd ed.). New York: The Free Press. Rogers, E. (1995). Diffusion of innovation (4th ed.). New York: The Free Press.

Sashkin, M., \& Egermeier, J. (1992). School change models and processes. A review and synthesis of research and practice. (ERIC No. ED 348 758)

Snow, C., \& Tabors, P. (1996). Intergenerational transfer of literacy [Online document]. Washington, DC: U.S. Department of Education. Available: www.ed.gov/pubs/FamLit/transfer.html.

U.S. Congress, Office of Technology Assessment. (1995). Teachers and technology: Making the connection (OTA-HER-616). Washington, DC: U.S. Government Printing Office.

Zimbardo, P. G., \& Leippe, M. (1991). The psychology of attitude change and social influence. Philadelphia: Temple University Press. 